INSIGHTS INTO REGIONAL DEVELOPMENT

ISSN 2669-0195 (online) http://jssidoi.org/IRD/

2020 Volume 2 Number 4 (December)

http://doi.org/10.9770/IRD.2020.2.4(2)

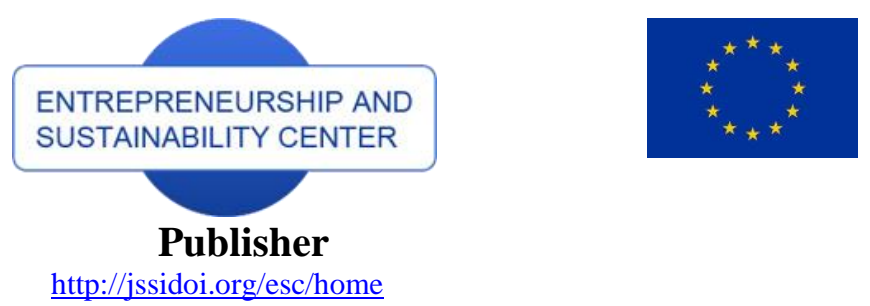

\title{
BOARD DIRECTOR REPUTATION CAPITAL AND FINANCIAL PERFORMANCE OF LISTED FIRMS IN NIGERIA
}

\author{
Peter Ehizokhale Okpamen ${ }^{1}$, Sunday Oseiweh Ogbeide ${ }^{2 *}$ \\ ${ }^{1}$ Department of Accounting and Finance, Faculty of Humanities, Social \& Management Sciences, Elizade University, \\ Ilara-Mokin, P.M.B. 002, Ondo State, Nigeria \\ ${ }^{2}$ Department of Business Administration, Faculty of Management Sciences, Ambrose Alli University, Ekpoma, Edo State, \\ Nigeria \\ E-mail:2 2 sunnyogbeide2017@gmail.com (Corresponding author)
}

\begin{abstract}
This study examined the impact of board director reputation capital on financial performance of listed firms in Nigeria. The population of the study consists of all the listed non- financial firms in Nigeria. A sample of fifty (50) firms was selected and data were collected over the period 2007 to 2018. Descriptive statistics and system general method of moment estimation methods were used to undertake the data analysis. Findings reveal that board director reputational capital exerted a positive and significant impact on financial performance of the firms. Board size and firm size were negative on firm financial performance in the reference period. The study concludes that board reputational capital is a significant driver of corporate financial performance in Nigeria irrespective of the size of the board. Based on the empirical findings, it is recommended that there is need for regulators to design a framework to efficiently and effectively monitor the reputation of executive board directors and managers in firms. This will assist to check mate agency costs, demonstration of opportunistic behavior capable of destroying the firm value, There is need for firms to encourage adequate interlocking members who have diverse professional training, high social net worth and experience (experience hypothesis) to positively influence effective management and financial performance of listed firms in Nigeria.
\end{abstract}

Key words: board reputational capital; board size; firm size; financial performance; Nigeria

Reference to this paper should be made as follows: Okpamen, H., \& Ogbeide, S.O. (2020). Board director reputation capital and financial performance of listed firms in Nigeria. Insights into Regional Development, 2(4).

JEL Classifications: M41 and M42 https://www.aeaweb.org/econlit/jelCodes.php?view=jel

\section{Introduction}

Performance of a firm is of utmost concern to shareholders and stakeholders generally. The performance of firms may be classified into firm and market based performance. Firm performance is a reflection of the effective expense management and strategies of the directors and their reputation. Firm financial performance is often captured with return on equity, return on assets, among others. Firm performance precedes market based performance. Market based performance captures the performance of firm in the market place. 


\section{INSIGHTS INTO REGIONAL DEVELOPMENT}

ISSN 2669-0195 (online) http://jssidoi.org/jesi/

2020 Volume 2 Number 4 (December)

http://doi.org/10.9770/IRD.2020.2.4(2)

Market based financial performance is more often a signal in the market regarding how well a company is doing. It often reflects in earnings per share, price earnings ratio, stock price, dividend per share, Tobin Q and others. Performance indicates the efficient management of a firm, assuring the resource owners of return on investment, increase in the market value and enhances the growth of the industry (Naser \& Mokhtar, 2004; Kaguri, 2013). Both firm and market based financial performance indicators are aspects of serious concern in fundamental analysis in finance domain. However, empirical finance and accounting researches often requires proxies for variables of interest with outright justification. Despite this, proxies need to be chosen carefully since inappropriate proxies could cause a hypothesis to be spuriously rejected or accepted.

Board directors are saddled with the responsibility of managing the resources of the owners - shareholders. They are expected to demonstrate competence, professionalism and integrity in the discharge of their assigned onerous duties to maximize the wealth of the shareholders and satisfy interest of other stakeholders in the business environments. One of the fundamental factors usually considered when appointing a director in a firm board, besides level of education, financial skills and years of experience is integrity. Integrity is necessary at effectuating fiduciary duty by board members. Integrity is a social intangible capital which has spiral positive effects in the firm. In the light of dynamism in corporate world, integrity on the part of board of directors may be regarded as a reputational capital. To protect their own reputational capital, board of directors do ensure adherence to quality accounting information disclosure, ethical standards and also demand for optimal performance with a view to attaining the goal of maximizing the wealth of the shareholders and other stakeholders at large (Fredriksson, Kiran \& Niemi, 2018). With increase in reputational capital by board directors, there is the likelihood for optimal performance demanded by them. Board directors are sometimes vehement at demanding for additional external assurance on financial statements if they are skewed at protecting their reputational capital. One of the attributes expected from board directors by shareholders and stakeholders is a good reputation. A potential investor do take into consideration the reputation of a firm and its directors before taking investment decision. Stakeholder such as suppliers might restrict credit lines if the board directors are perceived to have a bad financial reputation. Thus, the reputational capital of board of directors is a mirror image of the core values of a firm which has consequential spiral effects. Board director reputation is fundamental to the effective, efficient management and success of a firm. It is the hub upon which minimization of agency costs hinge on in a firm. Through it, directors avoid the tendency to engage in rent extraction and thereby enhance the firm market value. A good reputation may be regarded as a social intangible capital to a company. The ability of board directors to enhance firm performance is largely dependent on the reputation they have. In today's corporate world, reputation of directors is one of the main value-drivers of corporate performance and it is an essential intangible asset affecting financial outcomes of firms worldwide (Velte, 2017).

Given the prevailing economic factors adversely affecting businesses globally and in the emerging market of Nigeria in specific, it is difficult for firms to may thrive successfully and operate optimalyy without reputational capital of directors in placed. Alan Greenspun (2001) cited in Klewes and Wreschniok (2009) surmise that overtime and in the past two decades, reputation has become the most important corporate value expected of directors by shareholders and other stakeholders to promote the operational and financial performance of companies. In the expression of Cao, Myers and Omer (2012), concern for reputation capital makes board directors to behave ethically in a way and manner that is in the interest of shareholders and other stakeholders. Reputational capital of board directors boosts their sense of responsibility as well as their specialized knowledge which in turn enhances their professional judgment about the operational and financial performances of firms (Du et al. 2017).

The collapse of firms such as Enron WorldCom(US), Parmalat, (Italy), Nortel, (Canada), Onetel (Australia), Lehman Brother and Merrill Lynch, American International Group (AIG), Oceanic and Intercontinental banks (Nigeria) may not be unconnected with board directors' questionable reputation. In the year 2009 in Nigeria for instance, the erstwhile Governor of the Central Bank of Nigeria, Mr. Sanusi Lamido Sanusi identified banks like 


\section{INSIGHTS INTO REGIONAL DEVELOPMENT}

ISSN 2669-0195 (online) http://jssidoi.org/jesi/

2020 Volume 2 Number 4 (December)

http://doi.org/10.9770/IRD.2020.2.4(2)

Union Bank PLC, Oceanic Bank PLC and others to be in a near state of insolvency. The unhealthy development was farther from ineffectiveness and non- adherence to ethical values of the affected firms.

Reputation of board of directors mainly consists of managerial reputation which may translates to product reputation and financial reputation of a firm. Managerial reputation is often associated with adherence to ethics and professionalism in the day-to- day systematic management of firms by executive directors. Product reputational capital which primarily concerns with the satisfaction derived by consumers of a firm's product is a function of board directors' reputation and core values. It also concerns how board directors actually follow the legal and structural processes leading to the production of the final product brought into the market place for sales and usage. Financial reputational capital of directors is about prudent handling of finances of the company gear towards the satisfaction of the resources owners. If directors amass wealth for themselves through higher remuneration and engagement in rent seeking, their financial reputational capital may be at stake. All things being equal, the higher the reputational capital of board of directors, better is the improvement in the overall operating and financial performances of a firm. While board director reputational capital are theoretically explored in literature, the empirical verifiability in the context of Nigeria is lacking.

The association between board director reputation capital and firms' financial performance has been relatively investigated in developed countries (e.g, Larcker \& Richardson, 2007; Jackson, 2015, Fich \& Shivdasani, 2007; Francis, Huang, Rajhopal \& Ziang, 2008; Fredriksson, Kiran \& Niemi, 2018). The researches (e.g Ingley and Walt, 2003; Nierderkofler (2019) on the effect of board director reputation on firm performance in developed markets are inconclusive. The research of Nierderkofler (2019) mainly focuses on corporate reputation and its translation to performance of firms. This study takes a departure from it to verify the relationship between board director reputational capital and the financial performance of listed companies in Nigeria. Similarly, apart from the theoretical juxtaposition of Iwu-Egwuonwu (2011) on the connectivity between corporate reputation and organization performance in Nigeria, no studies in the context of the emerging market of Nigeria to the best of our knowledge which have empirically determine impact of board director reputation capital contributes on firm financial performance, hence this study is undertaken with a view to contributing to the debate. albeit, the empirical assessment of the impact of board director reputational capital towards firms financial performance in emerging market of Nigeria is yet to attract researchers' attention considerably.

\section{Literature Review}

\subsection{Theoretical Framework}

This study relies on ethical theory to examine the link between board director reputational capital and firm financial performance. Ethics with finding agreement, disagreement and judgments regarding right or wrong, good or bad, virtue or vice and states of affairs of a system (Booth et al., 2005). An ethical theory offers a set of related ideas that identify how individuals ought to live or how an organization should be coordinated ethically (Thiroux \& Krasemann, 2009). The theory suggests that an action can only be right if and only if it ratifies the principle of utility like dependence of right of action on its consequences. Ethical theory posits that individual in performing their duties must learn the importance of telling the truth, acting on the fairest way possible and also be able to ensure all promises are kept (Alzeban, 2018). Ethical theory implies that the different actors who are entrusted with the strategic management of a firm are less likely to engage in unethical behaviour to obtain financial rewards (Rose, 2015). The thrust of shareholders committing their investment resources into the hands of board directors is primarily hinged on ethical stance.

Using the ethical theory, reputational capital of board director are supposed to influence a firm financial performance and quality financial reporting. It requires adherence to ethical standards by corporate board director mechanisms to influence the operational performance and ensuring compliance with the accounting standards for quality financial reporting and performance disclosure. So, adherence to ethical behaviour portrays that managers 


\section{INSIGHTS INTO REGIONAL DEVELOPMENT}

ISSN 2669-0195 (online) http://jssidoi.org/jesi/

2020 Volume 2 Number 4 (December)

http://doi.org/10.9770/IRD.2020.2.4(2)

conscientiously manage the resources of the shareholders, report every business activities in the day to day management of a company. Ethics in corporate governance is very much inclined in the organization's goals and framework. This varies depending on the organization since there are cases that an organization is closed or limited only to some investors in maintaining control of the ownership. Nonetheless this should not be an issue if there are no unethical decisions being made by those in charge of decision-making conferring to (Hasnan, Rahman, \& Mahenthiran, 2013). This study holds the view that ethical theory connects board director reputational capital and financial performance of listed firms.

\subsection{Empirical Review}

Good reputation is an enduring asset to a firm in these days of corporate dynamism. Researchers over the years have continued to express concern on the need for reputation adherence by board directors in firms. IwuEgwuonwu (2011) avers that for ages, the view that corporate reputation positively impacts on firm performance has been recorded. The author stresses further that accounting and finance literature support the idea that corporate reputation brings a large wealth which often is embedded in a firm goodwill. Iwu-Egwuonwu (2011) opines that some conventional wisdoms point that the reputation firms orchestrate, do bring about sustainable profits always. Reputation is an intangible asset and it is currently being researched as a source of sustainable advantages and performance in corporate organizations. In today's corporate world, what is being refers to as brand equity is in essence the corporate reputation (Iwu-Egwuonwu, 2011). On the empirical front, Nguyen, Locke and Reddy (2017) sought to investigate if human capital of board directors adds value to firm in Asian market. The dynamic system generalized method of moments (system GMM) estimator was employed to analyze the panel data-set consisting of 315 firm- year observation over a four- year period from 2008 to 2011. The findings indicate that board director reputational capital have positive influence upon the firms' financial performance in Vietnam. James and Roh (2015) in a study titled: revisiting corporate reputation and firm performance link report that corporate reputations are significant and positive drivers of corporate performance measures.

Ingley and Walt (2003) found no causal relationship between corporate reputation and financial performance. This may be due to weaknesses in the existing measure of reputation, or due to unobserved variability in the intervening variable of managerial exploitation of the reputation. Nierderkofler (2019) research shows that corporate reputation has a strong positive association with operating performance indicators, viz-a-viz sales growth and profit margins. Similarly, the research fails to reveal any evidence of a significant correlation between corporate reputation and operating performances and operating expenses or salaries expenses. It can be observed that the research of Nierderkofler (2019) mainly focuses on corporate reputation. This study takes a departure from it to verify the relationship between board of director reputational capital and the financial performance of listed companies in Nigeria. This study hypothesis that board director does not have significant effect on firm financial performance in Nigeria.

\section{Methodology}

Since this study examines the impact of board director reputational capital on firm financial performance, this causal-research is employed. Fifty (50) listed non- financial firms were selected using the simple random sampling technique in the period 2007 to 2018. This represents six hundred firm- annual observation. Descriptive statistics and two step system general method of moment (SGMM2) were employed to analyze the data. The second step system general method of moment (SGMM2) unlike the first and second steps differenced GMM, explicitly provides consistent estimates even if endogeneity, heteroscedasticity and serial correlation problems occur in the analysis (Alhad et al. 2018). IT gives more efficient results than difference GMM even with unbalanced panel data since it employs more instruments and consists of both level and first difference regression (Roodman, 2009). Second step System GMM takes care of endogeneity problems and fixed effects in addition to the fact it removes dynamic panel bias (Nickell, 1981 as cited in Dahir et al., 2018). Additionally, second step 
system GMM is preferred and appropriate with small times series data. Diagnostic tests were used to determine the BLUE (best, linear, unbiased estimate) of the properties of the model. The model used is in the study is as follow:

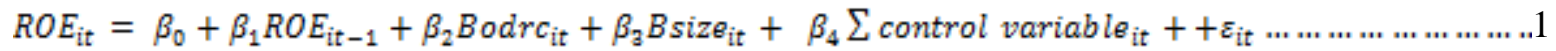

Where,

$R O E_{i t}=$ return on equity of $i$ firm in $t$ period; Bodr $c_{i t}=$ Board direction reputational capital of $i$ firm in $t$ period; Bsize $_{i t}=$ Board size of $i$ firm in $t$ period and $\sum$ Control variables $_{i t}=$ consists of firm size; $i=$ Individual firm in the sample size; $t=$ Period the study covers; $\varepsilon=$ Error term acting as a surrogate in the models and $\beta_{0}=$ Intercept.

Table 1. Procedures used to measure the variables

\begin{tabular}{|c|c|c|c|c|}
\hline $\mathbf{S} / \mathbf{N}$ & Variables & $\begin{array}{l}\text { Type of } \\
\text { Variables }\end{array}$ & Measurements & Sources \\
\hline 3. & $\begin{array}{l}\text { Board Director Reputational } \\
\text { Capital }\end{array}$ & $\begin{array}{l}\text { Independent } \\
\text { Variable }\end{array}$ & $\begin{array}{l}\text { Measured as the total compensation directors earn from their } \\
\text { directorships. }\end{array}$ & $\begin{array}{l}\text { Fredriksson et al., } \\
2018\end{array}$ \\
\hline 5. & Firm Size & $\begin{array}{l}\text { Independent } \\
\text { Variable }\end{array}$ & Natural logarithm of total Assets & \\
\hline
\end{tabular}

Procedures used to measure the variables are presented in table 1 above.

\section{Empirical Results and Discussion}

The empirical result in this sub- section starts with summary statistics, diagnostics tests results and the baseline second step system general method of moment (SGMM2) on the variables of the study. The second step system general method of moment (SGMM2) is employed to analyze the direct effect of board director reputational capital on the sampled firms' financial performance.

\subsection{Descriptive statistics and multicollinearity test}

This part reports the descriptive statistics and multicollinearity test results of the variables in the dynamic panel regression model. Table 2 concerns the test of multicollinearity among the explanatory variables. The average variance inflation factor (VIF) of 3.640 is less than 10 and thus indicates absence of multicollinearity among the independent variables in the model.

Table 2. Variance Inflation Factor Test (VIF)

\begin{tabular}{lccc}
\hline Variable & U/VIF & VIF & 1.067 \\
BODRC & 16.996 & 1.041 & 1.066
\end{tabular}


INSIGHTS INTO REGIONAL DEVELOPMENT

ISSN 2669-0195 (online) http://jssidoi.org/jesi/ 2020 Volume 2 Number 4 (December) http://doi.org/10.9770/IRD.2020.2.4(2)

FSIZE

137.081

1.532

\begin{tabular}{|c|c|c|c|c|c|c|}
\hline Mean VIF & & & & & & 3.640 \\
\hline \multicolumn{7}{|c|}{ Table 3. Descriptive Statistics of Variables } \\
\hline Variables & Observation & Mean & STD & Skewness & Kurtosis & Jarque-Bera \\
\hline ROE & 593 & 9.67 & 173.94 & 4.18 & 170.27 & $\begin{array}{l}693095.8 \\
P-V=0.00 * * *\end{array}$ \\
\hline BODRC & 593 & 64.88 & 16.81 & -0.55 & 3.38 & $\begin{array}{l}34.12 \\
\mathrm{P}-\mathrm{V}=0.00 * * *\end{array}$ \\
\hline BSIZE & 593 & 10 & 0.15 & 6.27 & 40.38 & $\begin{array}{l}38418 \\
P-V=0.00 * * *\end{array}$ \\
\hline FSIZE & 593 & N7.159106 & 0.76 & 0.25 & 2.66 & $\begin{array}{l}9.14 \\
\mathrm{P}-\mathrm{V}=0.00 * * *\end{array}$ \\
\hline
\end{tabular}

The table 3 represents the variables in the construct. ROE represents return on equity; BODRC represents board director reputational capital; BSIZE represents board size while FSIZE represents firm size.

Table 3 shows that return on equity (ROE) ranges from a low of approximately $10 \%$, suggesting the firms' shareholders experienced about $10 \%$ in the return on equity investment in the reference period. This may not be unconnected with interplay of effective governance system and adherence to ethical values by board directors of the sampled firms. The skewness value of -2.15 of return on equity implies the variable was symmetrical around its mean in the period observed. The kurtosis of 22.52 value suggests the distribution leptokurtic. The Jargue-Bera statistics of 9876.19 with P-value of 0.00 is statistically significant at $5 \%$ level, an indication that the data was normally distributed.

On an average, board of director reputational capital has the highest mean value of 94.44 percent with a standard deviation of 16.81. This suggests high reputation of the board members and practices of good corporate governance towards enhancing the firm and investors' confidence in the stock market. The skewness is negative while the kurtosis is positive and platykurtic, implying the distribution is flat around mean of the variable in the period. The Jargue-Bera value of 34.12 with a probability value of $0.00(\mathrm{P}=0.00)$ is statistically significant at $5 \%$ level. It is an indication that the variable is normally distributed in the period.

Firm size mean value is 7.15910 billion and high mean value of 9.220000 billion naira in the reference period. It is an indication that the sampled firms are highly capital intensive by way of fixed assets investments. The result is consistent with the empirical finding of Ilaboya et al. (2016) of 7.303577 billion. The mean value of board size (B-SIZE) is 10 with a variation from the mean of 0.15 . The composition of the board is relatively large and may not be helpful in mitigating conflicts in decision making.

\subsection{Diagnostic Test and Dynamic Panel Regression Results}

Table 4. Panel Model Diagnostics

\begin{tabular}{|l|l|c|}
\hline \multicolumn{1}{|c|}{ Tests } & \multicolumn{1}{|c|}{ F-Statistics } & Probability Values \\
\hline Breusch-Pagan Godfrey Heteroscedasticity & 1.773 & $0.0162^{* *}$ \\
\hline Breusch-Godfrey Autocorrelation & 137.807 & $0.000^{* * *}$ \\
\hline Ramsey Rest Test of Misspecification & 1.206 & $0.0211^{* * *}$ \\
\hline$* *$ is significant at 5\% &
\end{tabular}

Table 4 shows the Breusch-Pagan Godfrey Heteroscedasticity test indicates the presence of homoscedasticity. The Breusch-Godfrey serial autocorrelation suggests absence of higher order 
INSIGHTS INTO REGIONAL DEVELOPMENT

ISSN 2669-0195 (online) http://jssidoi.org/jesi/

2020 Volume 2 Number 4 (December)

http://doi.org/10.9770/IRD.2020.2.4(2)

autocorrelation. The Ramsey Reset Test of misspecification result shows the dynamic panel model was correctly specified and provides evidence of non- linearity.

Table 5. Board Director Reputational Capital and Return on Equity (ROE)

\begin{tabular}{lcccc}
\hline & $(1)$ & $(2)$ & $(3)$ & $(4)$ \\
BODRC & POLS & FE & PDLS & SGMM \\
& $0.06^{*}$ & $0.21^{*}$ & $0.00^{* * *}$ & $0.06^{* * *}$ \\
BSIZE & {$[0.14]$} & {$[0.34]$} & {$[0.00]$} & {$[0.04]^{* * *}$} \\
& $-21.07^{*}$ & $-1.35^{* * *}$ & $-23.02^{*}$ & $-21.07^{* * *}$ \\
FSIZE & {$[0.66]$} & {$[0.00]$} & {$[0.19]$} & $0.22]$ \\
& $0.60^{*}$ & $20.49^{* * *}$ & $2.65^{* * * *}$ & {$[0.96]$} \\
C & {$[0.95]$} & {$[0.05]$} & {$[0.05]$} & $10.37^{*}$ \\
& $10.37^{*}$ & $151.00^{*}$ & - & {$[0.93]$} \\
ROE(-1) & {$[0.90]$} & {$[0.56]$} & - & $0.81^{* * *}$ \\
& & & & {$[0.00]$} \\
\hline R-Squared & & 0.78 & 0.60 & 0.83 \\
Adjusted R-Square & 0.64 & 0.69 & 0.52 & - \\
F-Statistics & 0.58 & 21.89 & - & - \\
Prob (F-Stat) & 2.47 & $0.00^{* * *}$ & - & - \\
Durbin-Watson Stat & $0.00 * * *$ & 2.01 & 2.07 & $9.35(0.00)^{* * *}$ \\
J-Statistics and P-Value & 1.83 & & & \\
\hline
\end{tabular}

The table represents the variables in the construct. ROE represents return on equity; BODRC represents board director reputational capital; BSIZE represents board size; FSIZE; represents firm size and values in parenthesis are t-statistical values; ${ }^{*} p<0.1,{ }^{* *} p<0.05,{ }^{* * *} p<0.01$.

The result of system GMM (SGMM) in Column (4), indicates that the coefficient value of the returns on equity (ROE) is positive and statistically significant at $95 \%$ level. It is suggestive that a period lag of return on equity (ROE) influences financial performance of firms in Nigeria.

Board director reputational capital (BODRC) is positive and has a significant coefficient value of 6\%. The finding suggests board director reputational capital is a key driver of financial performance of firms and shareholders wealth maximization in Nigeria. As board director reputational mechanism increases, financial performance increases also, holding other factors constant. The result agrees with the findings of Du et al. (2017) and Fredriksson et al., (2018) that to protect their own reputational capital, board directors do ensure adherence to quality accounting information disclosure, ethical standards and also demands for optimal performance with a view to attaining the goal of maximizing the wealth of the shareholders and other stakeholders at large.

Board size has negative coefficient value of 21.07 on return on equity (ROE) of the firms. The finding is suggestive that a relatively large board size engenders conflicts in decision making and may hampers financial performance of firms. The finding correlates with Igbinosa and Ogbeide (2016); Darmadi (2013) which reported a negative and insignificant impact of board size on financial performance in firms. Firm size is positive and insignificant on the firm performance in the reference period.

\section{Conclusion and Recommendations}

The effect of board reputational capital on firms in the light of global economic challenges cannot be overemphasized. It presumably takes a center stage in the management of the affairs of firms generally. Albeit, the incessant collapse of firms and corporate scandals after the reports of statutory auditors in the emerging market like Nigeria precipitated the need to empirically examine the nexus between reputations of board directors as a capital and financial performance of listed firms in the context of Nigeria.

The study concludes that board reputational capital is a significant driver of corporate financial performance in Nigeria irrespective of the size of the board. Based on the empirical findings, it is recommended that there is need 


\section{INSIGHTS INTO REGIONAL DEVELOPMENT}

ISSN 2669-0195 (online) http://jssidoi.org/jesi/ 2020 Volume 2 Number 4 (December) http://doi.org/10.9770/IRD.2020.2.4(2)

for regulators to design a framework to efficiently and effectively monitor the reputation of executive board directors and managers in firms. This will assist to check mate agency costs, demonstration of opportunistic behavior capable of destroying the firm value, There is need for firms to encourage adequate interlocking members who have diverse professional training, high social net worth and experience (experience hypothesis) to positively influence effective management and financial performance of listed firms in Nigeria.

\section{References:}

Carter, D.A., D'souza, F., Simkins, B.J., \& Simpson, W.G. (2010). The gender and ethnic diversity of U.S boards and boards committees and firm financial performance. Corporate: An International Review, 18(5), 398-414.

Darmadi, S. (2013). Do women in top management affect firm performance? Evidence from Indonesia. The International Journal of Business in Society, 13(3), 288-304. http://dx.dox/10.1108/GG-12-2010-0096.

Du, X., Jian, W., \& Lai, S. (2017). Do foreign directors mitigate earnings management? Evidence from China. International Journal of Accounting, 30(40), $1-36$.

Eagly, A. H. (1987). Sex differences in social behavior: A social-role interpretation. Hillsdale, NJ: Lawrence Erlbaum.

Eagly, A. H., \& Johnson, B. T. (1990). Gender and leadership style: A meta analysis. Psychological Bulletin, 108, $233-256$.

Fredriksson, A., Kiran, A., \& Niemii, L. (2018). Reputation capital of directorships and audit quality. M.Sc thesis presented in Turuku School of Economics, Aalto University School of Business.

Geletkanycz, M.A., \& Boyd, B.K. (2011). CEO outside directorship and firm performance: a reconciliation of agency and embeddness views. Academy of Management Journal. 54, 335-354.

Igbinosa, S.O., \& Ogbeide, S.O. (2015). Corporate board diversity and stock price performance: Evidence from Nigeria. Journal of Business \& Value Creation, 4(1), 98-116.

Ilaboya, O.J., Obasi, R \& Izevbekhai, M.O (2016). Firm level characteristics and effective tax rate. ICAN academic conference proceedings, 573-593.

Ingley, C., \& Walt, N. (2003). Do board processes influence director and board performance? Statutory and performance implications. Corporate Governance: An international Review, 13, 632-653.

Iwu-Egwuonwu, R.C. (2011). Corporate reputation and firm performance: empirical literature evidence. International Journal of Business and Management, 6(4), 197-206.

Klewes, A., \& Wreschnick, W. (2009). The effect of IFRS on earnings management in Brazilian non financial public companies. Emerging Markets Review, 21, 42 - 66. http://dx.dox/10.1016/j.ememar.2009.07.009

Marimuthu, M., \& Koladasamy, L. (2009). Ethnic and gender diversity in board of directors and their relevance to financial performance of Malaysian Companies. Journal of Sustainable Development, 2(3), 139-148.

Nierderkofler, T. (2019). Reputational Capital and operating performance. A press media approach. Free University of Bolzano, Italy.

Oyeleke, O.E.O., Erin. O., \& Emeni, F. (2016). Female directors and tax aggressiveness of listed banks in Nigeria. $3^{\text {rd } I n t e r n a t i o n a l ~}$ conference on African development issues covenant university press, 293-299.

Sarkar, D., \& Sarkar, J. (2009). Meta-analytic review of board composition, leadership structure, and financial performance. Strategic Management Journal, 19, 269-290. 
INSIGHTS INTO REGIONAL DEVELOPMENT

ISSN 2669-0195 (online) http://jssidoi.org/jesi/ 2020 Volume 2 Number 4 (December)

http://doi.org/10.9770/IRD.2020.2.4(2)

Sawir, A. (2005). Analisis Kinerja Keuangan dan Perencanaan Keuangan Perusahaan. Jakarta: Penerbit Gramedia Pustaka Utama.

Velte, P. (2017). Do women on boards of directors have an impact on corporate governance quality and firm performance? A literature review. International Journal of Sustainable Strategic Management, 5(4), 302-346. 10.1504/IJSSM.2017.10010121

Dr. Peter Ehizokhale OKPAMEN is a Senior Academic in the Department of Business Administatrion, Faculty of Management Sciences, Ambrose Alli University, Ekpoma; Edo State, Nigeria. He holds the Bachelor of Science (B.Sc) degree in mathematics, postgraduate diploma in computer science and Master of Business Administration (MBA) from the University of Benin, Master of Science (M.Sc) in Advanced Information Technology, London and Doctor of Philosophy (PhD Management) from the Enugu State University of Technology (ESUT). Master of Science (M.Sc.) degree in Businss Administration and Doctor of Philosophy (Ph.D. Management) degree from Ambrose. His area of specliazation include Business Management and Entrepreneurship Development.

ORCID ID: https://orcid.org/0000-0002-2710-9431

Dr. Sunday Oseiweh OGBEIDE is an Active Researcher in, and Lecturer of Finance in the Department of Accunting and Finance, Faculty of Humanities, Social \& Management Sciences, Elizade University, P.M. B. 002, Ilara-mokin, Ondo State, Nigeria. He holds the Bachelor of Science (B.Sc) degree in Accounting, Master of Science (M.Sc. Finance) degree and Doctor of Philosophy (Ph.D. Finance) degree from the prestigious University of Benin, Edo State, Nigeria. There are over 12000 reads of his articles by researcher all over the world. His area of specliazation include Standard Finance and Behaviuoral Finance.

ORCID ID: https://orcid.org/0000-0002-2818-7757

Register for an ORCID ID:

https://orcid.org/register

Copyright (C) 2020 by author(s) and VsI Entrepreneurship and Sustainability Center

This work is licensed under the Creative Commons Attribution International License (CC BY).

http://creativecommons.org/licenses/by/4.0/

(c) (i) Open Access 